Jurnal Media Agribisnis Vol. 2 No. 1 Tahun 2017 Hal 1 - 12

Media Komunikasi Hasil Penelitian Bidang Ilmu Agribisnis

ISSN 2541-6898

\title{
HUBUNGAN ASPEK SOSIAL DENGAN KEPUTUSAN NELAYAN \\ DALAM PEMASARAN HASIL PERIKANAN TANGKAP DI KABUPATEN TANJUNG JABUNG BARAT
}

\author{
Asmaida \\ Program Studi Agribisnis, Fakultas Pertanian Universitas Batanghari \\ Jl. Slamet Riyadi-Broni, Jambi. 36122. Telp. +6274160103 \\ email korespondensi : asmaida.syandri@yahoo.co.id
}

\begin{abstract}
This study aims to find out fishermen descrition involving :1) relationship between knowledge and product marketing decision. 2) The relation between trust and their decision in product marketing. Survey method was used in this research on two districts selected purposively. Chi Square test was used to know the relation between knowledge and trust with . produk marketing decision, hence the relationship closeness was calculated by its contingency degree. The results of this reserch showed: 1) there was a significantlty correlation between knowledge and product marketing decision, $\left(\chi^{2}\right.$ $(32,143)>\chi_{\text {table }}^{2}(3,481)$ at $\left.\alpha=5 \%\right)$, with strong relationship (0.43). 2) there was a significanttly relationship between the trush level with the . product marketing decision $\left(\chi^{2}(9,964)>\chi_{\text {tabel }}^{2}(3,481)\right.$ at $\alpha=5 \%$, but had less strong relationship closeness $(0,255)$.
\end{abstract}

Keywords: Knowledge Level, trush Level, Decision of Fisherman

\begin{abstract}
Abstrak
Penelitian ini bertujuan untuk melihat : 1) Hubungan pengetahuan dengan keputusan dalam pemasaran hasil perikanan tangkap. 2) Hubungan kepercayaan dengan keputusan dalam pemasaran hasil perikanan tangkap. Metode yang digunakan dalam penelitian ini adalah metode survei terhadap dua kecamatan di Kabupaten Tanjung Jabung Barat yang dipilih secara purposif. Dalam penelitian ini uji Chi Square, digunakan untuk melihat hubungan antara pengetahuan dan kepercayaan dengan keputusan dalam pemasaran hasil produk yang selanjutnya keeratan hubungan dapat terlihat dengan menghitung derajat kontingensinya. Hasil penelitian menunjukan : 1) terdapat hubungan yang nyata antara pengetahuan dengan keputusan dalam pemasaran hasil perikanan tangkap, dimana nilai $\chi^{2}$ hit $(32,143)>\chi_{\text {tabel }}^{2}(3,481)$ pada derajat kesempurnaan $95 \%$, dengan memiliki derajat keeratan hubungan yang kuat $(0,43)$. 2) terdapat hubungan yang signifikan antara tingkat kepercayaan dengan keputusan pemasaran produk dalam pemasaran hasil produk $\left(\chi^{2}(9,964) \geq \chi_{\text {tabel }}^{2}\right.$ $(3,481))$ pada $\alpha=5 \%$, dengan keeratan hubungan yang kurang kuat $(0,255)$.

Kata Kunci : Tingkat Pengetahuan, Tingkat Kepercayaan, Keputusan Nelayan Tangkap
\end{abstract}


Jurnal Media Agribisnis Vol. 2 No. 1 Tahun 2017 Hal 1 - 12

Media Komunikasi Hasil Penelitian Bidang Ilmu Agribisnis

ISSN 2541-6898

\section{PENDAHULUAN}

Sebagai negara kepulauan Indonesia memiliki potensi beragam sumberdaya kelautan dan perikanan yang sangat pontensial dan produktif serta memiliki nilai ekonomi yang tinggi. Potensi sumberdaya kelautan dan perikanan tersebut bila dimanfaatkan secara optimal dapat menjadi penggerak utama perekonomian nasional yang pada akhirnya diharapkan dapat meningkatkan kesejahteraan masyarakat (Dahuri, 1996).Salah satu potensi sumberdaya kelautan dan perikanan yang telah memberikan kontribusi yang cukup signifikan bagi perekonomian Indonesia adalah subsektor perikanan tangkap. Hasil produksi perikanan di Indonesia berasal dari usaha penangkapan di laut.

Daerah Kabupaten Tanjung Jabung Barat memiliki potensi perikanan tangkap yang cukup besar dengan luas areal 77.752 hektar dengan panjang garis pantai $191 \mathrm{~km}$ yang terbentang dari perbatasan Kabupaten Tanjung Jabung Barat sampai dengan perbatasan Propinsi Sumatera Selatan, dengan potensi produksi perikanan tangkapnya mencapai 114.036 ton per tahun.Wilayah Kabupaten Tanjung Jabung Barat merupakan wilayah kabupaten yang berhubungan langsung dengan perairan sehingga sebagian besar penduduknya bekerja sebagai nelayan dan menjadikan usaha perikanan tangkap ini sebagai sumber pendapatan mereka dalam usaha memenuhi kebutuhan sehari-hari dan usaha untuk meningkatkan taraf kesejahteraan hidup (Dinas Kelautan dan Perikanan Kabupaten Tanjung Jabung Barat, 2015).

Pesatnya perkembangan hasil produksi perikanan, khususnya di daerah Kabupaten Tanjung Jabung Barat tentu memberi sumbangan yang besar tehadap pendapatan asli daerah yang berasal dari produksi usaha perikanan tangkap, sayangnya dalam hal ini masih belum diikuti dengan peningkatan kesejahteraan nelayan, hal ini terlihat sebagian besar nelayan masih hidup dibawah garis kemiskinan. Nilai ekonomi yang cukup besar dari hasil produksi perikanan justru lebih banyak dinikmati oleh pelaku ekonomi diluar nelayan. Salah satu faktor penyebab berlangsungnyakemiskinan nelayan diduga belum efesien dan efektifnya sistim pemasaran ikan.Dalam hal pemasaran, nelayan di daerah Kabupaten Tanjung Jabung Barat, keputusannya dalam memasarkan hasil perikanan tangkapnya tidak tergantung pada satu saluran pemasaran saja, tetapi dapat memasarkan ke berbagai bentuk saluran pemasaran yaitu menjual kepedagang pengumpul (toke) dan juga dapat menjual selain ke pedagang pengumpul, seperti ke Tempat Pelelangan Ikan (TPI), eksportir dan pedagang pengencer. Ada beberapa fenomena yang terjadi pada nelayan dalam pemasaran hasil perikanan tangkap, ada yang memilih memasarkan ke pedagang pengumpul tampa keterikatan dan ada juga yang menjalin keterikatan dengan pedagang pengumpul.Secara umum perilaku nelayan yaitu keputusan dalam memasarkan hasil tangkapannya tentu mempunyai hubungan dengan aspek sosial (pengetahuan dan kepercayaan nelayan) dalam memilih saluran pemasaran. Permasalahan yang akan dibahas dalam penelitian ini adalah :

1. Bagaimana tingkat pengetahuan dan kepercayaan nelayan dalam pemasaran hasil perikanan tangkap di Kabupaten Tanjung Jabung Barat?

2. Bagaimana keputusan nelayan dalam pemasaran hasil perikanan tangkap di Kabupaten Tanjung Jabung Barat?

3. Adakah hubungan antara tingkat pengetahuan dan kepercayaan dengan keputusan nelayan dalam pemasaran hasil perikanan tangkap di Kabupaten Tanjung Jabung Barat? 
Jurnal Media Agribisnis Vol. 2 No. 1 Tahun 2017 Hal 1 - 12

Media Komunikasi Hasil Penelitian Bidang Ilmu Agribisnis

ISSN 2541-6898

Adapun tujuan dalam penelitian ini adalah untuk mengetahui tingkat pengetahuan, tingkat kepercayaan dan keputusan nelayan dalam pemasaran hasil perikanan tangkap serta hubungan antara tingkat pengetahuan dan kepercayaan dengan keputusan nelayan dalam pemasaran hasil perikanan tangkap tersebut.

\section{METODOLOGI PENELITIAN}

Ruang lingkup penelitian ini membahas hubungan antara aspek sosial (pengetahuandan kepercayaan) dengan keputusan nelayan dalam pemasaran hasil perikanan tangkap di Kabupaten Tanjung Jabung Barat, tepatnya diKecamatan Tungkal Ilir dan Kecamatan Kuala Betara. Lokasi penelitian ditentukan secara sengaja (purposive sampling) dengan pertimbangan bahwa daerah tersebut merupakan daerah pesisir pantai dan mayoritas mata pencarian penduduknya adalah sebagai nelayan (Kabupaten Tanjung Jabung Barat, 2015)

Penelitian ini menggunakan metode survei. Menurut Silalahi, U. 2010, bahwa survei adalah suatu usaha untuk mendapatkan dan mengumpulan data dan informasi dari berbagai sumber. Dalam hal ini adalah nelayan sebagai sumber data primer, dengan tehnik pengumpulan data secara observasi, wawancara dan pengisian kuisioner yang terpola dan terstruktur sesuai dengan kebutuhan akan data yang mengacu pada tujuan penelitian, sedangkan data sekunder diperoleh dari berbagai literatur yang berasal dari lembaga dan instansi terkait.

Dalam pengumpulan data dilakukan penarikan sampel, Tasri, E,S, (2007), menyatakan sampel adalah kumpulan dari unit sampling yang merupakan subset dari populasi atau bagian tertentu yang dipilih dari populasi. Sampel dapat digunakan dalam penelitian, dengan tujuan untuk menghemat biaya, mempercepat pelaksanaan penelitian, menghemat tenaga, memperluar ruang lingkup penyajian, dan memperoleh hasil yang lebih akurat. Selanjutnya sampel dapat digunakan apabila keadaan subjek populasi homogen. Berdasarkan uraian tersebut, maka digunakanlah sampel dalam penelitian ini.

Menentukan jumlah sampel keseluruhan berdasarkan pernyataan Winarno, $\mathrm{S}$ dalam Tasri E,S(2007), bila populasi cukup homogen, terhadap populasi dibawah 100 dapat digunakan sampel sebesar $50 \%$ dan bila populasi diatas 100 maka besarnya sampel adalah $15 \%$, sedangkan untuk manusia sebaiknya diatas 30 orang. Maka diambil sampel sebesar 15\% (143 orang) dari total populasi nelayan (956 orang), secara acak (simple random sampling).

Menentukan besarnya sub sampel tiap kecamatan dengan rumus proporsional sampling (Nazir, 1999) $: n_{i}=\frac{N_{i}}{N} \cdot n \quad \ldots \ldots . .1$

Dimana :

$$
\begin{aligned}
& \mathrm{N}=\text { Jumlah total populasi nelayan } \\
& \mathrm{Ni}=\text { Jumlah sub populasi nelayan } \\
& \mathrm{n} \text { = Jumlah total sampel nelayan } \\
& \mathrm{ni}=\text { Jumlah sub sampel nelayan }
\end{aligned}
$$

Jumlah sub sampel untuk Kecamatan Tungkal Ilir sebanyak 103 dari 691 orang dan untuk Kecamatan Kuala Betara sebanyak 40 dari 265 orang.

Untuk menganalisis data yang diperoleh dari lapangan digunakan beberapa metoode analisis sesuai dengan tujuan penelitiann, yaitu sebagai berikut : 
Jurnal Media Agribisnis Vol. 2 No. 1 Tahun 2017 Hal 1 - 12

Media Komunikasi Hasil Penelitian Bidang Ilmu Agribisnis

ISSN 2541-6898

Pengukuranpengetahuan dan kepercayaan nelayan menggunakan data kualitatif dengan skala ordinal yang diangkakan dengan menggunakan skoring sehingga menjadi data kuantitatif. Dimana setiap jawaban telah diberi bobot nilai (Umar, 2007), yaitu sebagai berikut:

a. Variabel pengetahuan :

Sangat mengetahui (ST), diberi bobot nilai $=5$

Kurang mengaetahui (KT), diberi bobot nilai $=3$

Tidak mengetahui (TT), diberi bobot nilai $=1$

Selanjutnya ditentukan jarak interval dengan mencari rentang skala dari kategori tingkat pengetahuan tinggi, jika skor $37-60$ dan tingkat pengetahuan rendah, jika skor $12-36$.

b. Variabel kepercayaan :

Sangat percaya (SP), diberi bobot nilai $=5$

Kurang percaya (KP), diberi bobot nilai $=3$

Tidak percaya $(\mathrm{TP})$, diberi bobot nilai $=1$

Selanjutnyaditentukan jarak interval dengan mencari rentang skala dari kategori tingkat kepercayaan tinggi, jika skor $52-85$ dan tingkat pengetahuan rendah, jika skor $15-51$.

Pengukuran keputusannelayan menggunakan data ratio.Keputusan merupakan keputusan yang pilih nelayan untuk menentukan kemana ikan hasil tangkapannya akan dipasarkan, yang dibagi dalam dua kategori :

Bebas = Nelayan memasarkan hasil tangkapannya bisa kepedagangpengumpul atau ke selain dari pedagang pengumpul, dengan persentase frekuensi pemasarannya ke pedagang pengumpul selama 6 bulan berturut-turut lebih kecil dari $50 \%$.

Terikat = Nelayan memasarkan hasil tangkapannya bisa kepedagangpengumpul atau ke selain dari pedagang pengumpul, dengan persentase frekuensi pemasarannya ke pedagang pengumpul selama 6 bulan berturut-turut lebih besar sama dengan dari $50 \%$.

Untuk mengetahui hubunganpengetahuan dan kepercayaan dengan keputusan nelayan dalam pemasaran hasil perikanan tangkap menggunakan data nominal dengan uji Chi Squarepadatabel kontingensi $2 \times 2$ dengan tabel derajat bebas $(\mathrm{db}=1)$ Sugiyono (2004):

$$
\chi^{2}=\frac{n(|a d-b c|-1 / 2 n)^{2}}{(a+b)(a+c)(b+d)(c+d)} \quad \ldots \ldots . . .2
$$

Dimana :

$n=$ Jumlah Sampel

$\chi^{2}=\chi^{2}$ Hitung

$\mathrm{a}, \mathrm{b}, \mathrm{c}$ dan $\mathrm{d}=$ frekuensi dalam masing-masing sel

Adapun tabelnya adalah seperti terlihat pada Tabel 1 . 
Jurnal Media Agribisnis Vol. 2 No. 1 Tahun 2017 Hal 1 - 12

Media Komunikasi Hasil Penelitian Bidang Ilmu Agribisnis

ISSN 2541-6898

Tabel 1. Hubungan Tingkat Pengetahuan dan Kepercayaan Dengan Keputusan Nelayan Dalam Pemasaran Hasil Perikanan Tangkap

\begin{tabular}{llll}
\hline \multirow{2}{*}{$\begin{array}{l}\text { Aspek sosial } \\
\text { Tingkat Pengetahuan dan }\end{array}$} & \multicolumn{2}{l}{$\begin{array}{l}\text { Keputusan Pemasaran Hasil } \\
\text { Kepercayaan) }\end{array}$} & \multirow{2}{*}{ Jumlah } \\
\cline { 2 - 3 } & Berikanan Tangkap & \\
\hline Tinggi & $\mathrm{A}$ & $\mathrm{b}$ & $\mathrm{a}+\mathrm{b}$ \\
\hline Rendah & $\mathrm{B}$ & $\mathrm{D}$ & $\mathrm{c}+\mathrm{d}$ \\
\hline Jumlah & $\mathrm{a}+\mathrm{c}$ & $\mathrm{b}+\mathrm{d}$ & $\mathrm{N}$ \\
\hline
\end{tabular}

Nilai $\chi^{2}$ tabel dengan derajat bebas $(\mathrm{db})=1$ pada tingkat kepercayaan $95 \%$ adalah 3,841 dengan kaidah keputusan sebagai berikut :

1. Terima $\mathrm{H}_{0}$ atau tolak $\mathrm{H}_{\mathrm{a}}$ jika nilai $\chi^{2}$ hitung $<\chi^{2}$ tabel

2. Tolak $\mathrm{H}_{0}$ atauterima $\mathrm{H}_{\mathrm{a}}$ jika nilai $\chi^{2}$ hitung $\geq \chi^{2}$ tabel

Dimana :

$\mathrm{H}_{0}=$ Tidak terdapat hubungan antara tingkat pengetahuan dan kepercayaandengan keputusan nelayan dalam pemasaran hasil perikanan tangkap di Kabupaten Tanjung Jabung Barat.

$\mathrm{H}_{\mathrm{a}}=$ Terdapat hubungan antara tingkat pengetahuan dan kepercayaan dengan keputusan nelayan dalam pemasaran hasil perikanan tangkap di Kabupaten Tanjung Jabung Barat.

Untuk melihat keeratan hubungan antara tingkat pengetahuan dan kepercayaan dengan keputusan nelayan dalam pemasaran hasil perikanan tangkapdigunakan uji korelasi kontigensi (Husaini Usman, 2006) :

$$
\mathbf{C}=\sqrt{\frac{\chi^{2}}{n+\chi^{2}}} \quad \ldots \ldots . .3
$$

Dimana:

$\mathrm{C}=$ Koefisien kontingensi, dengan nilai terletak antara $0-0,707$ dengan kaidak keputusan adalah :

$\mathrm{C}=0-0,353$ adalah menunjukan hubungan kurang kuat

$\mathrm{C}=0,354-0,707$ adalah menunjukan hubungan yang kuat

$\mathrm{n}=$ Jumlah sampel

$\chi=\chi^{2}$ hitung

\section{HASIL DAN PEMBAHASAN}

\section{Karakteristik Responden}

Dalam penelitian ini yang menjadi responden adalah nelayan yang melakukan kegiatan usaha perikanan tangkap dan yang langsung melakukan pemasaran hasil tangkapannya di Kabupaten Tanjung Jabung Barat sebanyak 143 orang. Adapun karakteristik responden yang akan dibahas dalam penelitian ini meliputi umur, tingkat pendidikan, jumlah tanggungan keluarga, dan lamanya pengalaman sebagai nelayan. 
Jurnal Media Agribisnis Vol. 2 No. 1 Tahun 2017 Hal 1 - 12

Media Komunikasi Hasil Penelitian Bidang Ilmu Agribisnis

ISSN 2541-6898

Tingkat umur nelayan mempunyai pengaruh terhadap kemampuan fisik nelayan dalam mengelola usahanya. Semakin tua umur nelayan, maka kemampuan fisik untuk bekerja relatif semakin menurun. Umur nelayan di daerah penelitian bervariasi batas umur yang termuda berumur 25 tahun dan yang tertua berumur 65 tahun, nelayan yang tergolong sebagai nelayan berusia produktif yaitu sebanyak 120 orangatau 83,92\%, sedangkan nelayan yang sudah tua dan tidak produktif lagi adalah sebanyak 23 orang atau $16,08 \%$, dengan umur rata-rata 38,47 tahun. Hal ini menunjukan bahwa di daerah penelitian jumlah nelayan yang usia produktif cukup besar, bearti memungkinkan untuk berusaha mencapai produksi yang lebih baik lagi. Selanjutnya usia juga akan mempengaruhi tingkat produktivitas nelayan dalam menjalankan usaha. Hal ini senada dengan yang dikemukakan oleh Fadholi Hernanto (1996), bahwa seseorang yang berumur muda akan relatif dinamik dan lincah dengan kondisi fisiknya, sedangkan nelayan yang sudah tua mulai diserang ketuaannya akan relatif kurang gesit.

Pendidikan mempunyai pengaruh bagi nelayan dalam mengadopsi teknologi dan keterampilan manajemen dalam menjalankan usahanya. Semakin tinggi tingkat pendidikan seseorang diharapkanpola pikirnya semakin rasional. Di daerah penelitian sebanyak 124 orang atau 86,52\% dari nelayan berpendidikan SD/Sederajat dan sebanyak 19 orang atau 13,48\% berpendidikan SLTP dan SLTA. Hal ini menunjukan bahwa tingkat pendidikan nelayan di daerah penelitian relatif rendah. Rendahnya tingkat pendidikan tentu akan mempengruhi tingkat pengetahuan nelayan. Hal ini sejalan dengan pendapat Saridewi (2010), yang menyatakan bahwa tingkat pendidikan seseorang dapat mengubah pola pikir, daya penalaran yang lebih baik, sehingga makin lama seseorang mengenyam pendidikan akan semakin rasional.

Jumlah anggota keluarga yang menjadi tanggungan kepala keluarga nelayan akan berpengaruh terhadap pengelolaan usaha yang diusahakannya. Semakin banyak jumlah tanggungan anggota keluarga maka semakin banyak kebutuhan yang harus dipenuhi oleh nelayan, sehingga memberikan konsekuensi untuk berusaha lebih menguntungkan. Menurut Fadholi Hernanto (1996), jumlah tanggungan keluarga nelayan berpengaruh terhadap kegiatan ekonomi pada usahanya. Jumlah anggota keluarga nelayan berkisar antara 1-9 orang, dengan rata-rata 4 orang per rumah tangga nelayan yang meliputi suami sebagai Kepala Rumah Tangga, isteri dan anak-anaknya.

Lamanya pengalaman dalam berusaha merupakan salah satu faktor yang berperan penting dalam hal tingkat pengambilan keputusan dalam berusaha. Lamanya pengalaman nelayan sampel dalam berusaha perikanan tangkap diukur dalam tahun sejak nelayan pertama kali mulai berusaha perikanan tangkap. Pengalaman nelayan dalam berusaha perikanan tangkap di daerah penelitian berkisar antara 5-50 tahun, dengan rata-rata lamanya berusaha sebagai nelayan adalah 15,98 tahun. Dari angka ini terlihat bahwa nelayan di daerah penelitian tergolong pada nelayan yang sudah berpengalaman. Pengalaman berusaha umumnya diperoleh nelayan secara turun temurun.

Pengalaman pahit tidak jarang menjadi kendala dalam mengambil suatu keputusan dan bahkan begitu menghantui seseorang sehingga ia menjadi takut dan raguragu dalam mengambil keputusan (Siagian, 2001). Artinya semakin lama pengalaman seseorang maka semakin berani dan mantap dalam mengambil keputusan, seperti keputusan nelayan pergi menangkap ikan dan keputusan dalam memasarkan hasil tangkapannya. 
Jurnal Media Agribisnis Vol. 2 No. 1 Tahun 2017 Hal 1 - 12

Media Komunikasi Hasil Penelitian Bidang Ilmu Agribisnis

ISSN 2541-6898

\section{Pengetahuan Nelayan dalam Memasarkan Hasil Tangkapan}

Pengetahuan nelayan yang dimaksud dalam penelitian ini adalah pemahaman nelayandalam pemasaran hasil perikanan tangkap, hal-hal yang dikaji untuk mengetahui tingkat pengetahuan nelayan adalah sebagai berikut :

a. Pengetahuan tentang tempat-tempat pemasaran hasil perikanan tangkap.

b. Pengetahuan tentang harga hasil perikanan tangkap.

c. Pengetahuan tentang kebiasaan menjual hasil perikanan tangkap.

Sesuai dengan konsepsi pengukuran, pengetahuan nelayan di daerah penelitian dikelompokan menjadi dua kategori yaitu kategori pengetahuan tinggi dan kategori pengetahuan rendah. Hasil penelitian tentang tingkat pengetahuan nelayan tersebut disajikan dalan Tabel 2.

Tabel 2. Frekuensi Nelayan Berdasarkan Kategori Tingkat Pengetahuan Dalam Pemasaran Hasil Perikanan Tangkap di Daerah Penelitian Tahun 2016

\begin{tabular}{|c|c|c|c|}
\hline No & Kategori Tingkat Pengetahuan & Frekuensi (orang) & Persentase $(\%)$ \\
\hline 1 & Tinggi & 34 & 23,78 \\
\hline 2 & Rendah & 109 & 76,22 \\
\hline Jum & & 143 & 100,00 \\
\hline
\end{tabular}

Sumber : Data primer diolah, tahun 2016

Dari Tabel 2 di atas, dapat dilihat bahwa pengetahuan nelayan dalam pemasaran hasil perikanan tangkap di daerah penelitian masih tergolong rendah, hal ini terlihat dari 143 responden sebanyak 109 orang atau 76,22\% memiliki pengetahuan rendah. Rendahnya tingkat pengetahuan nelayan terhadap aspek-aspek pemasaran hasil tangkapan dapat disebabkan oleh beberapa faktor, antara lain karena kurangnya kepedulian nelayan terhadap keadaan sekitar, kurangnya mendapat informasi tentang perkembangan harga hasil tangkapan dan tingkat pendidikan nelayan yangrendah yaitu mayoritas hanya berpendidikan sekolah dasar sehingga mempengaruhi cara berfikir dan penerimaan terhadap hal-hal baru yang akan berdampak pada keputusan nelayan dalam memasarkan hasil tangkapan.

Selanjutnya Tabel 2 di atas, juga memperlihatkan hanya terdapat sebanyak 34 orang atau $23,78 \%$ nelayan yang memiliki tingkat pengetahuan tinggi terhadap aspekaspek pemasaran hasil perikanan tangkap. Hal ini juga disebabkan oleh beberapa faktor, antara lain karena adanya sosialisasi yang dilakukan oleh pihak instansi terkait melalui berbagai kegiatan penyuluhan dan informasi yang disampaikan secara berantai dari seseorang atau kelompok kepada seseorang atau kelompok lainnya.

\section{Kepercayaan Nelayan Dalam Pemasaran Hasil Tangkapan}

Kepercayaan nelayan yang dimaksud dalam penelitian ini adalah merupakan segala sesuatu yang menunjukkan sejauh mana keyakinan atau pemahaman nelayan terhadap tindakan yang dilakukan lembaga saluran pemasaran dalam pemasaran hasil perikanan tangkap. Hal-hal yang dikaji untuk mengetahui tingkat kepercayaan nelayan adalah dengan menggunakan indikator sebagai berikut :

a. Kepercayaan terhadap ketepatan ukuran timbangan pedagang pengumpul.

b. Kepercayaan terhadap harga yang ditetapkan pedagang pengumpul.

c. Kepercayaan terhadap keamanan menjual hasil tangkapan ke pedagang pengumpul.

d. Kepercayaan terhadap bantuan dan pinjaman yang diberikan pedagang pengumpul.

Sesuai dengan konsepsi pengukuran, kepercayaan nelayanterhadap tindakan yang dilakukan lembaga saluran pemasaran dalam pemasaran hasil perikanan tangkap 
Jurnal Media Agribisnis Vol. 2 No. 1 Tahun 2017 Hal 1 - 12

Media Komunikasi Hasil Penelitian Bidang Ilmu Agribisnis

ISSN 2541-6898

di daerah penelitian dikelompokan menjadi dua kategori yaitu kategori kepercayaan tinggi dan kategori kepercayaan rendah.

Kepercayan nelayan di daerah penelitian berdasarkan hasil penelitian menunjukkan bahwa nelayan masih tergolong tinggi kepercayaannya terhadap tindakan yang dilakukan pedagamg pengumpul dalam pemasaran hasil perikanan tangkap.Hasil penelitian tentang tingkat pengetahuan nelayan tersebut disajikan dalan Tabel 3.

Tabel 3.Frekuensi Nelayan Berdasarkan Tingkat Kepercayaan Nelayan Dalam Pemasaran Hasil Perikanan Tangkapan di Daerah Penelitian Tahun 2016.

\begin{tabular}{llcc}
\hline No & Kategori Tingkat Kepercayaan & Frekuensi (orang) & Persentase $(\%)$ \\
\hline 1 & Tinggi & 94 & 65,79 \\
\hline 2 & Rendah & 49 & 34,21 \\
\hline Jumlah & 143 & 100,00
\end{tabular}

Sumber : Data primer diolah, tahun 2016

Dari Tabel 3 di atas, dapat dilihat bahwa dari 143 orang nelayan terdapat 94 orang atau $65,79 \%$ yang memiliki kepercayaan tinggi dalam pemasaran hasil perikanan tangkap ke pedagang pengumpul, sedangkan nelayan yang memiliki kepercayaan rendah hanya sebanyak 49 orang atau 34,21\%. Kepercayaan nelayan ini timbul (tinggi) karena beberapa alasan yakni : pedagang pengumpul selalu memberikan kemudahan dalam transaksi jual beli hasil tangkapan, pelayanan yang baik dari pedagang pengumpul, pedagang pengumpul mau memberikan nelayan bantuan baik dalam bentuk uang maupun dalam bentuk lainnya untuk kebutuhan usaha penangkapan maupun untuk kebutuhan hidup keluarga nelayan. Semakin tinggi kepercayaan nelayan terhadap pedagang pengumpul maka kemungkinan untuk terikat kepada pedagang pengumpul semakin kuat.

Hal ini sesuai dengan pernyataan Das dan Teng (1998), kepercayaan merupakan sebagai derajat dimana seseorang yang percaya menaruh sikap positif terhadap keinginan baik dan keandalan orang lain yang dipercayanya di dalam situasi yang berubah-ubah dan beresiko. Selanjutnya Doney et al (1998), juga menyatakan bahwa kepercayaan sebagai sesuatu yang diharapkan dari kejujuran dan prilaku kooperatif yang berdasarkan saling berbagi norma-norma dan nilai yang sama. Sedangkan Soekanto (1998), menyatakan bahwa kepercayaan merupakan suatu perasaan yang dapat timbul sebagai hasil hubungan langsung antara dua orang atau lebih yang bersifat asosiatif.

\section{Keputusan Nelayan Perikanan Tangkap Dalam Memasarkan Hasil Tangkapan}

Keputusan nelayan yang dimaksud dalam penelitian ini adalah merupakan keputusan yang pilih nelayan untuk menentukan kemana ikan hasil tangkapannya akan dipasarkan, dalam hal ini untuk mengetahui tingkat keputusan nelayan adalah dengan menggunakan indikator sebagai berikut :

1) Bebas, nelayan memasarkan hasil tangkapannya bisa kepedagangpengumpul atau ke selain dari pedagang pengumpul, dengan persentase frekuensi pemasarannya ke pedagang pengumpul selama 6 bulan berturut-turut lebih kecil dari 50\%.

2) Terikat, nelayan memasarkan hasil tangkapannya bisa kepedagangpengumpul atau ke selain dari pedagang pengumpul, dengan persentase frekuensi pemasarannya ke pedagang pengumpul selama 6 bulan berturut-turut lebih besar sama dengan dari $50 \%$.

Salusu (2006), menyatakan bahwa pengambilan keputusan ialah proses pemilihan alternatif cara bertindak dengan metode yang efisien sesuai 
Jurnal Media Agribisnis Vol. 2 No. 1 Tahun 2017 Hal 1 - 12

Media Komunikasi Hasil Penelitian Bidang Ilmu Agribisnis

ISSN 2541-6898

situasi.Pernyataan ini menegaskan bahwa mengambil keputusan memerlukan satu seri tindakan yang membutuhkan beberapa langkah. Langkah-langkah itu terdapat dalam pikiran seseorang yang sekaligus mengajaknya berfikir sistematis.

Pengambilan keputusan berkaitan dengan keputusan nelayan di daerah penelitian dalam pemasaran hasil tangkapannya atau kemana hasil tangkapannya akan dijual. Hasil penelitian tentang keputusan nelayan tersebut disajikan dalan Tabel 4.

Tabel 4. Distribusi dan Frekuensi Nelayan Berdasarkan Keputusan Nelayan Dalam Pemasaran Hasil Perikanan Tangkapan di Daerah Penelitian Tahun 2016

\begin{tabular}{llcc}
\hline No & Kategori Keputusan & Frekuensi (orang) & Persentase (\%) \\
\hline 1 & Terikat & 114 & 79,74 \\
\hline 2 & Bebas & 29 & 20,26 \\
\hline Jumlah & 143 & 100,00 \\
\hline
\end{tabular}

Sumber : Data primer diolah, tahun 2016

Dari Tabel 4 di atas, terlihat bahwa bahwa dari 143 orang nelayan terdapat 114 orang atau $79,74 \%$ yang kategori keputusannya terikat dengan pedagang penggumpul, sedangkan nelayan yang kategori keputusannya bebas dalam memasarkan hasil tangkapannya hanya sebanyak 29 orang atau 20,26\%. Kategori keputusan terikat, terlihat dari frekuensi pemasaran selama periode waktu 6 bulan berturut-turut, rata-rata persentase frekuensi nelayan memutuskan untuk memasarkan hasil tangkapannya kepada pedagang penggumpul sebesar $63.89 \%$, sedangkan persentase frekuensi memasarkan hasil tangkapannya keselain pedagang pengumpul hanya 29,96\%.

Keputusan nelayan memasarkan hasil tangkapan ke pedagang pengumpul umumnya di dasarkan pada beberapa alasan, antara lain : tingginya tingkat kepercayaan nelayan terhadap pedagang pengumpul, nelayan bisa mendapatkan uang secara tunai, apabila nelayan mendapat kesulitan pedagang pengumpul mau memberikan pinjaman uang, sehingga tidak mempunyai keinginan untuk mencari tempat pemasaran yang lebih tepat, minimnya informasi harga ikan yang berlaku di tempat pelelangan ikan (TPI) atau di pasar, serta hasil tangkapan bersifat musiman dan mudah rusak untuk itu harus segera dijual.

\section{Hubungan Pengetahuan dengan Keputusan Nelayan DalamPemasaran Hasil Tangkapan}

Seorang nelayan akan bertindak atau memutuskan sesuatu apabila ia memiliki pengetahuan mengenai sesuatu yang akan ia lakukan atau ia putuskan. Pengetahuan itu didapat nelayan dari pendidikan, pengalaman sendiri atau orang lain. Apabila nelayan tersebut memiliki pengetahuan yang cukup mengenai suatu hal maka ia akan cepat merespon. Hal ini juga terjadi apabila nelayan memiliki pengetahuan yang cukup mengenai aspek-aspek dalam pemasaran hasil perikanan tangkap tentu saja akan berpengaruh pada keputusan nelayan dalam menjual hasil tangkapan.

Hasil penelitian tentang hubungan tingkat pengetahuan dengan keputusan nelayan dalam pemasaran hasil perikanan tangkap tersebut disajikan dalan Tabel 5. 
Jurnal Media Agribisnis Vol. 2 No. 1 Tahun 2017 Hal 1 - 12

Media Komunikasi Hasil Penelitian Bidang Ilmu Agribisnis

ISSN 2541-6898

\begin{tabular}{|c|c|c|c|c|c|c|}
\hline \multirow{3}{*}{$\begin{array}{l}\text { Tingkat } \\
\text { Pengetahuan }\end{array}$} & \multicolumn{4}{|c|}{ Keputusan Nelayan } & \multirow{3}{*}{$\begin{array}{l}\text { Jumlah } \\
\text { (Orang) }\end{array}$} & \multirow{3}{*}{$\begin{array}{l}\text { Persentase } \\
(\%)\end{array}$} \\
\hline & \multicolumn{2}{|l|}{ Terikat } & \multicolumn{2}{|l|}{ Bebas } & & \\
\hline & $\begin{array}{l}\text { Jumlah } \\
\text { (Orang) }\end{array}$ & $\begin{array}{l}\text { Persentase } \\
(\%)\end{array}$ & $\begin{array}{l}\text { Jumlah } \\
\text { (Orang) }\end{array}$ & $\begin{array}{l}\text { Persentase } \\
(\%)\end{array}$ & & \\
\hline Tinggi & 15 & 10,53 & 19 & 13,25 & 34 & 23,78 \\
\hline Rendah & 99 & 69,21 & 10 & 7,01 & 109 & 76,22 \\
\hline Jumlah & 114 & 79,74 & 29 & 20,26 & 143 & 100,00 \\
\hline
\end{tabular}

Sumber : Data primer diolah, tahun 2016

Dari hasil tabulasi silangdata pada Tabel 5 di atas, terlihat bahwa tingkat pengetahuan nelayan hampir berbanding lurus dengan keputusan yang diambil nelayan dalam pemasaran hasil perikanan tangkap.Nelayan yang tingkat pengetahuannya rendah sehingga keputusannya dalam pemasaran hasil tangkapannya terikat kepada pedagang pengumpul. Dari 143 nelayan terdapat 109 orang atau 76,22\% memiliki pengetahuan rendah, dan dari 109 orang yang berpengetahuan rendah tersebut sebanyak 99 orang atau $69,21 \%$ kategori keputusannya dalam pemasaran hasil tangkapannya adalah terikat dengan pedagang pengumpul dan sebanyak 10 orang atau 7,01\% kategori keputusannya bebas untuk memasarkan hasil tangkapannya dari pedagang penggumpul.

Selanjutnya nelayan yang berpengetahuan tinggi hanya sebanyak 34 orang atau $23,78 \%$, dan dari 34 orang nelayan yang berpengetahuan tinggi tersebut sebanyak 15 orang atau $10,53 \%$ kategori keputusannya dalam pemasaran hasil perikanan tangkap juga terikat dengan pedagang penggunpul dan sebanyak 19 rang atau 13,25\% kategori keputusannya bebas untuk memasarkan hasil tangkapannya dari pedagang penggumpul.

Nelayan yang keputusannya kategori bebas dalam memasarkan hasil tangkapan sebanyak 29 orang atau 20,26\%, keputusan bebas ini selain dipengaruhi oleh tingkat pengetahuan juga dipengaruhi oleh keputusan pihak lain yaitu sipemilik alat tangkap yang digunakan dalam berusaha oleh nelayan, karena sebagian besar nelayan dalam menjalankan usaha penangkapan ikan alat tangkap yang mereka gunakan adalah milik orang lain.

Hasil uji statistik non parametrik dengan menggunakan uji Chi Square diperoleh nilai $\chi_{\text {hitung }}^{2}$ sebesar 32,143, jika dibandingkan $\chi_{\text {tabel }}^{2}$ dengan $\mathrm{df}=1$ dan $\alpha=5 \%$ sebesar 3,481 maka nilai $\chi_{\text {hitung }}^{2} \geq \chi_{\text {tabel }}^{2}$ sehingga diambil kesimpulan yaitu menolak $\mathrm{H}_{0}$ atau menerima $\mathrm{H}_{\mathrm{a}}$. Hal ini berarti terdapat hubungan antara tingkat pengetahuan dengan keputusan nelayan dalam memasarkan hasil tangkapan di daerah penelitian.Hal ini menunjukan bahwa tingkat pengetahuannelayan berpengaruh terhadap keputusan nelayan dalam pemasaran hasil tangkapan di daerah penelitian atau pengatahuan yang dimiliki nelayan dalam pemasaran hasil tangkapan berdampak pada keputusan nelayan dalam memasarkan hasil tangkapan.

Apabila dilanjutkan dengan mengukur derajat kontingensi atau keeratan hubungan antara kedua variabel tersebut, maka diperoleh nilai sebesar 0,43 yang berarti antara tingkat pengetahuan nelayan dengan keputusan nelayan dalam memasarkan hasil tangkapan memiliki hubungan kuat.

\section{Hubungan Tingkat Kepercayaan dengan Keputusan Nelayan Dalam Memasarkan Hasil tangkapan}

Hubungan tingkat kepercayaan yang dimaksud adalah nelayan percaya dan yakin bahwa pedagang pengumpul dapat dipercaya, bertanggung jawab, jujur dan 
Jurnal Media Agribisnis Vol. 2 No. 1 Tahun 2017 Hal 1 - 12

Media Komunikasi Hasil Penelitian Bidang Ilmu Agribisnis

ISSN 2541-6898

penolong dalam kegiatan pemasaran hasil perikanan tangkap. Rasa percaya nelayan dan keyakinan yang dimilikinya terhadap pedagang pengumpul tersebut akan mempengaruhi nelayan dalam mengambil keputusan kepada siapa hasil tangkapannya akan dipasarkan.

Hasil penelitian tentang hubungan tingkat kepercayaan nelayan dengan keputusan nelayan dalam memasarkan hasil tangkapan disajikan pada Tabel 6.

Tabel 6. Hubungan Tingkat Kepercayaan dengan Keputusan Nelayan Dalam Pemasaran Hasil Tangkapan Tangkapan di Daerah Penelitian Tahun 2016

\begin{tabular}{lllllll}
\hline \multirow{2}{*}{$\begin{array}{l}\text { Tingkat } \\
\text { Kepercayaan }\end{array}$} & \multicolumn{3}{l}{ Keputusan Nelayan } & $\begin{array}{l}\text { Jumlah } \\
\text { (Orang) }\end{array}$ & $\begin{array}{l}\text { Persentase } \\
(\%)\end{array}$ \\
\cline { 2 - 5 } & Terikat & \multicolumn{3}{c}{ Bebas } \\
\cline { 2 - 5 } & $\begin{array}{l}\text { Jumlah } \\
(\text { Orang) }\end{array}$ & $\begin{array}{l}\text { Persentase } \\
(\%)\end{array}$ & $\begin{array}{l}\text { Jumlah } \\
(\text { Orang) }\end{array}$ & $\begin{array}{l}\text { Persentase } \\
(\%)\end{array}$ & \\
\hline Tinggi & 90 & 63,27 & 4 & 2,52 & 94 & 65,79 \\
\hline Rendah & 24 & 16,47 & 25 & 17,74 & 49 & 34,21 \\
\hline Jumlah & 114 & 79,74 & 29 & 20,26 & 143 & 100,00 \\
\hline
\end{tabular}

Sumber : Data primer diolah, tahun 2016

Dari hasil tabulasi silang pada Tabel 6 di atas, menyatakan bahwa nelayan di daerah penelitian memiliki tingkat kepercayaan tinggi terhadap pedagang pengumpul dalam pemasaran hasil perikanan tangkap, sehingga mereka terikat memasarkan hasil tangkapannya kepedagang pengumpul. Dari 143 orang nelayan terdapat 49 orang atau $34,21 \%$ yang memiliki tingkat kepercayaan rendah terhadap pedagang pengumpul, dan dari 49 orang tersebut sebanyak 24 orang16,47\%kategori keputusannya dalam pemasaran hasil tangkapannyaterikat dengan pedagang pengumpul dan sebanyak 25 orang atau $17,74 \%$ keputusannya bebas untuk memasarkan hasil tangkapannya dari pedagang penggumpul.

Selanjutnya nelayan yang mempunyai tingkat kepercayaan tinggi adalah sebanyak 94 orang atau $65,79 \%$, dan dari 94 orang tersebut sebanyak 90 orang atau $63,27 \%$ kategori keputusannya dalam pemasaran hasil tangkapannya adalah terikat dengan pedagang pengumpulsedangkan dan sebanyak 4 orang atau 2,52\% keputusannya bebas untuk memasarkan hasil tangkapannya dari pedagang pengumpul.

Alasan nelayan memasarkan hasil tangkapan ke pedagang pengumpul dengan keputusan terikat karena modal yang mereka gunakan untuk operasional usaha penangkapan diperoleh dari bantuan berupa pinjaman yang diberikan oleh pedagang pengumpul, pedagang pengumpul selalu memberi pertolongan setiap kali nelayan mengalami kesulitan dan transaksi penjualan bisa dilakukan di tempat mana saja.

Hasil uji statistik non parametrik dengan menggunakan uji Chi Square diperoleh nilai $\mathrm{X}^{2}$ hitung sebesar 9,964 jika dibandingkan $\mathrm{X}_{\text {tabel }}^{2}$ dengan $\mathrm{df}=1$ dan $\alpha=5 \%$ sebesar 3,481 maka nilai $\mathrm{X}_{\text {hitung }}^{2} \geq \mathrm{X}_{\text {tabel }}^{2}$ sehingga diambil kesimpulan bahwa menolak $\mathrm{H}_{0}$ dan menerima $\mathrm{H}_{\mathrm{a}}$. Hal ini berarti terdapat hubungan antara tingkat kepercayaan dengan keputusan nelayan dalam memasarkan hasil tangkapan di daerah penelitian.

Apabila dilanjutkan dengan mengukur derajat kontingensi, maka diperoleh nilai sebesar 0,255 yang berarti terdapat derajat hubungan yang kurang kuat antara tingkat kepercayaan dengan keputusan nelayan dalam memasarkan hasil tangkapan.Hal ini menunjukan bahwa tingkat kepercayaan berpengaruh terhadap keputusan nelayan dalam pemasakan hasil tangkapan di daerah penelitian atau kepercayaan yang dimiliki nelayan 
Jurnal Media Agribisnis Vol. 2 No. 1 Tahun 2017 Hal 1 - 12

Media Komunikasi Hasil Penelitian Bidang Ilmu Agribisnis

ISSN 2541-6898

kepada pedagang pengumpul berdampak pada keputusan nelayan dalam memasarkan hasil tangkapan.

\section{KESIMPULAN}

Hasil penelitian menunjukan bahwa di daerah penelitian :

1. Sebanyak $76,22 \%$ atau 109 orang nelayantingkat pengetahuannya dalam pemasaran hasil perikanan tangkap masih rendah dan sebanyak $65,79 \%$ atau 94 orangnelayanmempunyai tingkat kepercayaantinggi kepada pedagang pengumpuldalam pemasaran hasil perikanan tangkap.

2. Sebanyak $79,74 \%$ atau 114 orang nelayan keputusannya dalam pemasaran hasil perikanan tangkap terikat dengan pedagang pengumpul.

3. Terdapat hubungan yang nyata antara tingkat pengetahuan dan kepercayaan dengan keputusan nelayan dalam pemasaran hasil perikanan tangkap. Derajat kontingensiantara dua variabel pengetahuan dengan keputusannelayan sebesar 0,430 ataumemiliki hubungan yang kuat, sedangkanderajat kontingensi antara variabel kepercayaan dengan keputusan nelayan sebesar 0,255 atau memiliki hubungan yang kurang kuat.

\section{DAFTAR PUSTAKA}

Dahuri, R. et al. Pengelolaan Sumber Daya Wilayah Pesisir dan Lautan secara Terpadu. Pradnya Paramita. Jakarta. 1996.

Dinas Kelautan dan Perikanan KabupatenTtanjung Jabung Barat. 2015. LaporanTahunan. Dinas Kelautan dan Perikanan Kabupaten Tanjung Jabung Barat.

Hernanto, F. 1996. Ilmu Usahatani. Penebar Swadaya. Jakarta.

Husein Umar. 2007. Metodelogi penelitian untuk Skripsi Dan Tesis Bisnis. PT. Raja Grafindo Persada. Jakarta.

Nazir, M. 1999. Metode Penelitian. Ghalia Indonesia jakarta.

Mueller, J. Daniel. 1992. Mengukur Sikap Sosial. Bumi Aksara. Jakarta

Saridewi, T.R. dan Siregar, A. N. 2010. Hubungan antara peran penyuluh dan adopsi teknologi oleh petani terhadap peningkatan produksi di Kabupaten Tasikmalaya. Jurnal Penyuluhan Pertanian Volume 5 No.1 Mei 2010. Diakses 5 Januari 2017.

Siagian, S.P. 2001. Teori dan Praktek Pengambilan Keputusan. Gunung Agung. Jakarta.

Silalahi, U. 2010. Metode Penelitian Sosial. PT.Refika Aditama. Bandung

Simamora, B. 2009. Panduan Riset Perilaku Konsumen. PT. Gramedia. Jakarta

Soekamto. 1998. Sosiologi Suatu Pengantar. Radja Grafindo Persada. Jakarta.

Sugiyono. 2004. Statistik Non Parametris Untuk Penelitian. CV. Alfabeta. Bandung.

Tasri, E.S. 2007. Metodologi Penelitian Ekonomi dan Bisnis. Bung Hatta University Press, Padang.

Usman, H. Akbar, Setiady. 2008. Pengantar Statistika . Bumi Aksara. Jakarta.

Winarno, S. 1994. Pengantar Penelitian Ilmiah (Dalam MetodeTtehnik). Penerbit Kanisius, Tarsito. Bandung. 